\title{
Economic and Social Factors of Voluntary Tax Compliance: Evidence from Bahir Dar City
}

\section{Manchilot Tilahun*}

Raya University College of Business and Economics, Maichew, Tigray, Ethiopia

*Corresponding author: Manchilot Tilahun, Raya University College of Business and Economics, Maichew, Tigray, Ethiopia, Tel: (+251) 034-877-0515; E-mail: tilahunmanchilot@gmail.com

Received date: Sep 18, 2018; Accepted date: Oct 04, 2018; Published date: Oct 11, 2018

Copyright: () 2018 Tilahun M. This is an open-access article distributed under the terms of the Creative Commons Attribution License, which permits unrestricted use, distribution, and reproduction in any medium, provided the original author and source are credited.

\begin{abstract}
The study was conducted with the aim of identifying economic and social factors of tax compliance behavior in Bahir Dar city administration business income taxpayers. Voluntary compliance behavior of the taxpayers is affected by various factors and identifying these factors in order to maintain voluntary compliance at satisfactory level and treating the factors accordingly should be the central premises of any tax system. Research approach with explanatory research design is used in the study by employing stratified random sampling to select the participants. This study was conducted by using 248 business income taxpayers from which the data was collected from through questionnaires and unstructured interviews. The results showed that factors such as fairness of the tax system, penalty, tax rate, perceptions of government spending and compliance cost were found to be the determinant factors that affect taxpayer's voluntary compliance. And therefore it is suggested that maintaining tax fairness, appropriate and moderate levels of penalty, spending the tax revenue on important and social projects, keeping tax rates to the minimum as much as possible and keeping compliance costs to the minimum can enhance the voluntary compliance of taxpayers.
\end{abstract}

Keywords: Bahir Dar city administration; Determinants of tax compliance; Tax compliance

\section{Introduction}

Tax is a mandatory charge imposed by the government without any expectation of quid pro quo. In other words, tax is a compulsory payment by the people to the government for which there is no direct return to the taxpayers [1].

Governments impose taxes for a multiple of purposes, but the major is to raise funds in order to cover public expenditures and on the other hand to properly allocate resources. Tax is the main source of revenue for the government [2].

According to the federal income tax proclamation number 286/2002 business income taxpayers are categorized into three categories, namely category "A", "B", and "C" based on their volume of sales and form of business. Category " $\mathrm{A}$ " includes any company incorporated under the tax law of Ethiopia having annual turnover of Birr 500,000 and more. Those who are categorized under category "A" have to maintain all records and accounts which will enable them to submit a balance sheet and profit and loss account disclosing the gross profit, general and administrative expenses, depreciation, and provisions and reserves together with supporting vouchers. Category ' $\mathrm{B}$ ' includes those enterprises having annual turnover of more than Birr 100,000 and less than Birr 500,000. This category of taxpayers must submit profit and loss statement at the end of the year. The law requires all entries in the records and accounts to be supported by appropriate vouchers. Category ' $\mathrm{C}$ ' unless already classified in categories 'A' and ' $\mathrm{B}$ ' include those taxpayers whose annual turnover is estimated by the Tax Authority at Birr 100,000 or less.
Andreoni et al. defines tax compliance as the willingness of taxpayers to act in accordance with the tax laws of the country [3]. It means true reporting of income or asset balance that is used to calculate tax liability, correct computation of the tax liability, timely filing of returns and timely payment of the amount due.

Roth et al. defines tax compliance as Compliance with reporting requirements implying that, timely filing of returns and reporting accurate tax liability in accordance with the internal revenue code, regulations and court decisions applicable at the time return filing [4]. This definition assumes that in order to comply with the tax law, one must declare the correct amount of income, expenses to which one is entitled and subsequently pay the correct amount of tax by the due date.

Tadesse and Goitom argue that like other developing countries, Ethiopia faces vaults in raising revenue to the required level in order to scale up the development endeavors [5]. Ethiopia has experienced a steadfast expenditure surplus over revenue for a long period of time. Tax noncompliance is socially harmful, as it can reduce revenue, distort labor market and weaken state stability by enriching perception of cheating and fraud. Reducing noncompliance can be effective if the reason for noncompliance by tax payers is known. Understanding the motivations underlying taxpayers' attitudes and behaviors toward voluntary compliance is valuable to the tax authority by providing them information that can help them which strategy is appropriate and effective to increase compliance [6].

\section{Statement of the problem}

The issue of tax compliance has gained more stress by researchers in the recent couple of decades because of increasing level of tax noncompliance and its consequence on the capacity of the government to raise revenue. Mckercher and Evans, advocate that taxpayer non- 
compliance is a continual and growing worldwide issue that is not readily addressed [7]. In most African countries, the domestic tax bases are undermined by widespread tax avoidance and evasion [8]. According to Samuel and Viswanadham, Ethiopia, one of the fastest growing economies with a highly authoritative tax authority has failed to finance its activities by its own means due to non-compliance even after a series of tax system reforms [9]. According to Abreha and Kahase, tax evasion and avoidance are problems faced by every tax system and the tax system of Amhara National Regional State is not an exception that taxpayers exploit loopholes of tax provisions to minimize or escape tax liability [10].

According to Olamide and Segun, tax compliance can be affected by many factors such as magnitude of compliance cost, the extent of penalty, perceived fairness of the tax system, awareness level of taxpayers and perceptions of government spending [11]. A study by Tilahun and Yidersal revealed that perception on government spending, perception on equity and fairness of the tax system, penalties, personal financial constraint, changes on current government policies, and referral group (friends, relatives etc.) are factors that significantly affect tax compliance [12]. Dealing with the issue of tax non-compliance requires at least some understanding of the factors that are fundamental to the individual taxpayer's decision whether to comply or not to comply with tax laws. However, factors which influence tax compliance are different from country to country and also from individual to individual [13]. Because of these reasons, tax compliance has been given a big emphasis by researchers because of increasing non-compliance especially tax evasion and its consequences on the capacity of government in raising public revenue. But most of the previous studies are done in developed countries. Tax compliance researches in developing countries are low in number. The study is different from previous researches by the type of research design and approach it adopts as well as by consideration of determinant factors of tax compliance. There are too low researches done to identify the determinant factors of tax compliance in Ethiopia in general and particularly in Bahir Dar city. Therefore the purpose of the study is identifying factors that affect compliance of business income taxpayers in Bahir Dar city.

\section{Objectives of the study}

General objectives: The general objective of the study is identifying factors affecting tax payer's voluntary compliance in Bahir Dar city business income taxpayers.

\section{Specific objectives: Specific objectives of the study are:}

- To examine the relationship between economic factors (perceptions of government spending, compliance cost, tax rates and extent of penalty) and compliance of taxpayers.

- To examine the relationship between institutional factors (organizational strength of tax authorities) and compliance of taxpayers.

\section{Review of Literature}

Tax compliance has been defined as compliance with reporting requirements, meaning that the taxpayer files all required tax returns at the proper time and that the returns accurately report tax liability in accordance with the internal revenue code, regulations and court decisions applicable at the time the return is filed [4]. An alternative definition has been offered by James and Alley that considers tax compliance in terms of the tax gap [5]. This is the difference between true individual income tax liability and that finally collected on a voluntary basis or by enforcement action. Generally, compliance can be understood as acting in accordance with the law and noncompliance is deviation from the law. Based on the above expressions the definition of tax compliance can be shortly refined as the desire or willingness of the taxpayers to act in accordance with the tax law and the voluntary effort they exercise to pay their tax liability on timely basis.

\section{Determinants of tax compliance}

The problem of tax compliance is as old as taxes themselves. Characterizing and explaining the observed patterns of tax noncompliance and ultimately finding ways to lessen it are of obvious importance to countries [3].

\section{Economic factors of tax compliance:}

Perceptions of Government spending: According to Palil, very few studies have been done on the effect of government spending on compliance behavior of taxpayers [14]. Taxpayers, and especially those who pay high amounts of tax, will be sensitive to what the government spends their money on [5]. Since taxpayer's perceptions are important in determining their compliance behavior, government should spend tax revenue on a careful manner, because the spending pattern of the government causes different levels of compliance [14]. A study by Niway and Wondwossen found that there is a positive and significant relationship between perceptions of government spending and tax compliance [15]. A quantitative research by in Mauritius has found that government spending does not impact the compliance behavior of Mauritanians [14].

Penalty: As per Oladdipupo and Obazee, if a taxpayer is required to file an income or excise tax return and fails to timely do so, a late filing penalty may be assessed [16]. Under all tax proclamations of Ethiopia two types of penalties are provided. These are administrative penalty and penalty by court of law. All tax proclamations of Ethiopia proclaim that taxpayers that fail to fulfill the requirements of tax liability are chargeable with penalties ranging from financial penalties to imprisonment which is high. Thus, the extent of statutory penalty is not low in the case of Ethiopia and cannot be raised as the cause of tax evasion. Lederman argues that penalizing tax evaders can cause to feel sure others that they are doing the right thing [17]. Park and Hyun in their study found that penalizing taxpayers when caught encouraged taxpayers to report the true income they earn [18]. This result shows positive relationship between penalty and tax compliance.

Compliance cost: According to Ketema, tax compliance costs represent the additional costs in terms of time, effort and financial expense [19]. Regarding the general compliance cost in Ethiopia, almost 90 percent of the taxpayers believe that the total compliance cost is high or very high. According to Ketema, high compliance cost convinces taxpayers to evade from paying as per the report of IMF, reducing compliance costs by providing businesses with advisory visits, simplified accounting requirements and free record-keeping software, reduced frequency for filing and online services are strategies that facilitate compliance $[19,20]$.

Tax rates: Even though the effect of tax rate on tax compliance is still unclear and questionable, Clotfelter stated that cutting tax rates is not the mere way of reducing tax evasion, while Kirchler views tax rate as an important factor that determines compliance decision [13,21]. An increase in tax rates will discourage tax compliance while reducing tax rate doesn't reduce tax evasion [13,22,23]. Allingham and Sandmo 
tried to discover the relationship between tax compliance and tax rates and concluded that taxpayer's decision either to comply or not, regardless of tax rates [13]. However, Tanzi have concluded that tax rates were negatively correlated with tax compliance [24]. In line with this Palil concluded that higher tax rate would lead to lower compliance [14].

\section{Social factors of tax compliance:}

Fairness of the tax system: Tax fairness is a concept of having equitable tax system. Fairness of the tax system is believed by the taxpayers and tax authority as one of the significant determinants of compliance decision [6]. From previous studies mixed results arise on the impact of fairness on tax compliance. Warneryd and Walerud suggest that perceived inequity in the tax system does not contribute to tax evasion, but it is used to rationalize non-compliant behavior [8]. On the other hand, Niway and Wondwossen found that if the tax payers feel that their tax burden is higher than other people within the same income group; their tax compliance probably decreases [25].

The effect of Referrals: Individual taxpayers do not live alone in this world and they have to interact with others in their daily life. Thus, influence of one person on another in their compliance is an important part of their continuous existence in society. Perception of peers not to comply with the tax laws resulted in the taxpayers' non-compliance action [26]. Decisions to comply or not are sometimes influenced by family members and friends [24]. A Behavioral research by Puspitasari and Meiranto states that peer groups have a strong impact on behavior, preferences and personal values of the individual person [27]. However, Hite found that there is no significant correlation between taxpayer non-compliance and knowing non-compliant peers [28]. This argument is also supported by the finding of Oladipupo and Obazee [16].

\section{Research Methodology}

This chapter discusses the adopted research design and approach, population of the study, sampling design, sample size determination, data type and method of data collection as well as method of data analysis.

As the researcher is going to formulate the relationship between dependent variable (tax compliance) and independent variables, explanatory research design is adopted. The emphasis here is on studying a situation or a problem in order to explain the relationships between variables.

The target population of the study is category ' $\mathrm{A}$ ' and ' $\mathrm{B}$ ' business income taxpayers of Bahir Dar city. According to the revenue authority of Bahir Dar city administration, the total number of category 'A' and ' $\mathrm{B}$ ' business income taxpayers is 2307. Among this category ' $\mathrm{A}$ ' comprises 920 taxpayers and category 'B' comprises 1387 taxpayers. The researcher selects these categories because they are required by law to maintain and submit books of accounts to the tax authority within the stipulated time and therefore category ' $C$ ' taxpayers are not relevant for the problem since they pay tax according to the income assessed/estimated by the assessment committee.

The type of sampling used in the study is stratified random sampling. Strata can be formed on the basis of common characteristics (in this case taxpayers are divided in to strata based on their annual turnover. i.e., category A or B) of the items to be put in each stratum. The sample is selected by using simple random sampling by following the method of proportional allocation under which the sizes of the samples from the different strata are kept proportional to the sizes of the strata. For the purpose of the study sample size is determined by using Yamane's formula [29]:

$$
\begin{aligned}
& n=N /\left[1+N(e)^{2}\right] \\
& n=\frac{2307}{1+2307(0.06)^{2}}=248 .
\end{aligned}
$$

Therefore sample size is determined to 248 business income taxpayers to which the questionnaire was distributed. The sample is allocated to each category (stratum) as follows:

$$
\begin{aligned}
& \text { Category } A=\frac{920}{2307} * 248=99 \\
& \text { Category } B=\frac{1387}{2307} * 248=149 .
\end{aligned}
$$

The study has used primary data collected by using structured questionnaires and unstructured interviews. The questionnaire is composed of closed ended questions designed on a likert scale. In order to collect more qualitative data unstructured interviews were employed. This is done by interviewing business income taxpayers of the city.

\section{Model specification}

Sometimes response categories are ordered but do not form an interval scale. There is a clear ranking among the categories, but the difference among adjacent categories cannot be treated as the same. Responses like these with ordered categories cannot be easily modeled with classical regression. Ordinary linear regression is inappropriate because of the non-interval nature of the dependent variable-the spacing of the outcome choices cannot be assumed to be uniform. Ordinal logit and probit models have been widely used for analyzing such data [28]. Some polychotomous dependent variables are inherently ordered. Although the outcome is discrete, the multinomial logit or probit models would fail to account for the ordinal nature of the dependent variable [28]. The ordered probit and logit models have come into fairly wide use as a frame-work for analyzing such responses. Because of its mathematical convenience and interpretation simplicity the researcher has employed ordered logit model.

The model for the determinants of voluntary tax compliance of business income taxpayers is:

\section{TCOMP $=$ f (FTS, PEN, TR, EFR, PGS, COMPC, $\varepsilon$ )}

Where:

TCOMP=Tax compliance for ordered multi choice strongly agree, agree, neutral, disagree and strongly disagree

\section{$\mathrm{TR}=\mathrm{Tax}$ rate}

COMPC $=$ Compliance cost

FETS=Fairness/ Equity of the tax system

PEN=Penalty

PGS=Perceptions of Government spending

$\mathrm{EFR}=\mathrm{Effect}$ of referrals

$\mathrm{e}=$ Classical random error term

TCOMP $=\beta 0+\beta 1 \mathrm{FTS}+\beta 2 \mathrm{EFR}+\beta 3 \mathrm{PGS}+\beta 4 \mathrm{PEN}$.

$+\beta 5 \mathrm{COMPC}+\beta 6 \mathrm{Tr}+\varepsilon$ 
Page 4 of 7

\section{Results and Discussion}

A total of 248 questionnaires were distributed to both category ' $\mathrm{A}$ ' and category 'B' sample business income taxpayers and of which 224 returned filled completely and properly. This shows that the response rate was around $90.32 \%$.

\section{Estimation and analysis of the ordered logit model}

This section gives a great emphasis to the ordered logit model regression model results. Since the equation in an ordered logit model is non-linear, only the signs of the coefficients can be interpreted (Table 1).

\begin{tabular}{|c|c|c|c|c|c|c|}
\hline Tcomp & Coef. & Std. Err. & $\mathbf{Z}$ & $P>Z$ & $95 \%$ Conf. & Interval \\
\hline Fts & 0.430689 & 0.140031 & 3.08 & 0.002 & 0.1562328 & 0.705145 \\
\hline Pen & 0.782944 & 0.188731 & 4.15 & 0 & 0.4130379 & 1.15285 \\
\hline Pgs & 0.421872 & 0.169469 & 2.49 & 0.013 & 0.0897186 & 0.754025 \\
\hline Compc & -0.45238 & 0.159552 & -2.84 & 0.005 & -0.7650985 & -0.13967 \\
\hline Efr & -0.17807 & 0.171858 & -1.04 & 0.3 & -0.5149025 & 0.158767 \\
\hline $\operatorname{Tr}$ & -0.78234 & 0.142691 & -5.48 & 0 & -1.062004 & -0.50267 \\
\hline /cut1 & -2.52859 & 0.993713 & & & -4.476232 & -0.58095 \\
\hline /cut2 & 1.424695 & 0.966202 & & & -0.4690256 & 3.318416 \\
\hline /cut3 & 4.663944 & 1.066889 & & & 2.57288 & 6.755007 \\
\hline
\end{tabular}

Table 1: Results of ordered logistic regression.

Fairness and compliance have positive and significant relationship. This relation is towards the argument

With regard to the effect of referrals (family, relative, friends, etc.) the study found a negative and statistically insignificant relationship. This indicates that taxpayers did not consider the issue of the effect of referent groups to be of essence in making their tax compliance decisions. This finding is consistent with the finding of research done in Indonesia by Inasius [31]. On the other hand, this result contradicts previous results shown by Clotfelter et al. [14,21].

With regard to taxpayer's perception of government spending and tax compliance, this study founds a positive and significant relationship. This result suggested that, if the government is spending the national revenue wisely for basic facilities, such as education, health, safety and public transportation, it is assumed that voluntary compliance of taxpayers will increase. In contrast, if taxpayers perceive that the government is spending too much on unnecessary things; taxpayers may feel cheated and attempt to evade. This result is also consistent with the findings of $[6,12-15,32,33]$. On the other hand Tadesse and Goitom found insignificant correlation between tax compliance and taxpayer's perception of government spending [5].

The study also found that there is a positive and significant relationship between penalty and tax compliance and hence fail to reject the fifth hypothesis. This relationship between penalty and tax compliance is towards the argument that severe penalties and sanctions used to achieve greater compliance level and curbs future actions of tax evaders. This finding is the same as findings [34]. Similar result was reported in Kasipillai et al. [33]. Chau and Leung claimed that tax penalty is an important factor influencing tax compliance behavior and the authors suggested that the fear of penalties would prohibit the noncompliance tendency [35]. Witte and Woodbury have established a significant relationship between the severity of criminal sanctions and tax compliance [23].
The result of the regression shows a statistically significant negative relationship between tax compliance and cost of complying. This finding is consistent with the finding of Ketema; who concludes that voluntary compliance of taxpayers is dominantly affected by high compliance costs (both financial and time compliance costs) [19]. Similarly, Mogeni found that compliance cost is a contributory factor on tax compliance (lower compliance cost is associated with high levels of tax compliance) [36].

Finally, tax rate has found having a negative and significant impact on tax compliance. This result is towards the argument that tax systems with low tax rates are most likely to be complied. In line with this Spicer and Becker and Clotfelter found that tax non-compliance is positively correlated with high tax rates [21,37]. Similarly, more evidences show that high tax rate is positively related with noncompliance and negatively related with tax compliance [38-40]. On the other hand there are other studies who found there is no relationship between tax rate and tax compliance. Modugu et al. found that tax rate do not have either negative or positive impact on tax compliance [41].

\section{Interview results}

As stated in the data collection methods part of the methodology section, unstructured interviews to business income taxpayers of Bahir Dar city was employed. This aims at obtaining the relationship between tax compliance and its determinant factors under consideration of the study.

As far as the study is concerned with the issues of determinants of tax compliance, the interviewed participants have reflected different ideas. Accordingly, most of the interviewees are unhappy with the current business income tax system and the remaining too low participants have a good feeling to the current business income tax system. 
Reasons for paying taxes: With respect to the reasons of paying taxes (complying with the tax law), the researcher has sought that majority of the respondents comply with the tax law because of it is an obligation imposed by the government. Additionally, some of the interviewees pay taxes because they assume that the tax they pay is important to the development of the country (expansion of infrastructures) and some of the participants have responded that their compliance is because of there is no any means of not paying (evading) taxes, fear of penalties and sanctions. The following are samples of views of participants:

"I think...paying a reasonable amount of tax is due to it is an obligation and knowing have no chance of avoiding it (tax)." (Participant 7, Male, category 'A' taxpayer).

".... I think most people comply with the tax law because they fear to be penalized and thus to avoid penalties." (Participant 9, Male, category ' $B$ ' taxpayer).

Reasons for non-compliance: In this study the researcher has sought to understand the reasons for taxpayer's non-compliance. However, during the interviews the, participants were generally asked about the possible reasons of not complying with the tax laws of the country. The results indicate that the respondents have responded differently. Generally, the comments of respondents were their non-compliance is due to lack of ability to pay, lack of fairness in the tax system, lack of awareness, peer influence (effect of referrals non-compliance behavior) and negative perceptions of government spending.

"We (taxpayers) may not comply with the tax laws as we do not receive a direct benefit from the government." (Participant 4, Male, category ' $B$ ' taxpayer).

"I think in most cases taxpayers try to evade taxes because they feel that the tax money has not been spent properly." (Participant 3, Male, category ' $B$ ' taxpayer).

"Taxpayers will not comply because I believe if the penalty is lower than the tax saving due to not complying with the tax law." (Participant 2, Female, category 'A' taxpayer).

Fairness of the tax system: Regarding taxpayer's perception of fairness, the respondents felt that the tax system is generally unfair and have an impact on compliance behavior. The result indicates that their tax liability is overstated, lack of horizontal as well as vertical fairness. Some of the views of participants are:

"I think high income earners are paying high amounts of tax, but, not everyone is paying his/her fair share of taxes..." (Participant 1, Male, category 'A' taxpayer).

"The tax we are paying is overstated according to our income....." (Participant 8, Male, category 'A' taxpayer).

"The services we receive from the government are low compared to our tax payment. For example there is shortage in the supplies of water and electricity...." (Participant 9, Male, category ' $B$ ' taxpayer).

Effect of Referrals and Compliance cost: Concerning the issue of effect of referrals, the majority of the interview participants have claimed that the doing (non-compliance) of other taxpayers do not affect their compliance behavior. Whereas one participant has commented that "I try to evade taxes because I know business owners who do not comply with the tax law and have never been penalized by the tax authority." In relation to the cost of compliance, most of the respondents have replied that their compliance costs (both financial and time) are high and have a negative impact on their compliance behavior. They have costs like transportation cost, time, payments to tax accountants for preparation of tax returns etc. but, the remaining small number of participants have said that their compliance costs (both financial and time compliance costs) are low and insignificant and they have no effect on their compliance with the tax law. This result indicates that compliance cost has a substantial effect on the compliance decision of business income taxpayers in the study area as in the results in the quantitative analysis. Among the comments received:

"The tax authority takes more time to answer our questions and grievances. There is no fast delivery of responses... we waste a lot of time..." (Participant 1, Male, category 'A' taxpayer).

Perceptions of government spending: With respect to spending pattern of the government, the respondents have different views. Only one respondent have said that "the government spends all the money collected from taxes wisely." But almost all of the respondents do not view the spending as good and fair. Some respondents say spending of the tax revenue by the government across regions and societies is not fair, some others say expansion of infrastructures is not well developed, government officials within a short period of time become rich (they use tax revenue to buy their own home and car), spending of money to low income generating (least important) projects for example, spending money to construct stadiums rather than construction of roads, factories, hospitals, schools, etc. Finally, the respondents have argue that perception of government spending as good, will increases their compliance behavior and vice versa.

Penalty: Concerning the issue of penalty, some of the respondents have been penalized by the tax authority before for the acts of failing/ late declaration of income, reporting lower income, late payment of taxes, evading taxes, providing misleading (factious) information to the employees of the tax authority, overstating deductions, etc. Majority of the respondents have not been penalized as they pay in order to avoid penalties and sanctions. The taxpayers who have been penalized have elaborated that penalty provided by the tax authority for their illegal act (non-compliance) is an exemplary to others and they have learned from it. This will curve future decisions of taxpayers who evade taxes and this result is similar with the result in the quantitative analysis.

Tax rate: With regard to tax rates used to calculate the business income tax, almost all of the participants claimed that it is generally high. Participants have clearly mentioned that their perception of tax rates as high have motivated them to evade and avoid taxes. The following are some of the responses:

"I think we do not comply properly as the system is not fair.. I think that with a fairer tax, I think that we would comply... we pay tax at a higher rate" (Participant 8, Male, Category 'A' taxpayer)

"I think in most cases, taxpayers will evade tax because they feel that they are paying at a higher tax rate..." (Participant 2, Female, Category 'A'taxpayer).

\section{Conclusions}

The main objective of this study is to identify factors affecting tax payer's voluntary compliance in Bahir Dar city business income taxpayers. The results of ordered logistic regression model revealed a statistical relationship between tax compliance and some of the factors 
that are considered in the study. Accordingly the findings of this thesis are presented below.

The study has found a positive and significant relationship between tax compliance and fairness of the tax system. This implies that making the tax system fair leads to higher levels of tax compliance behavior of the taxpayers.

Evaluation of the effects of awareness level of taxpayers on tax compliance levels had revealed that there is a statistically insignificant and negative relationship between them.

The study had also examined the effects of compliance decisions of referrals on others compliance decision. The findings show a negative but insignificant relationship between them which implies that business income taxpayers in Bahir Dar city make their compliance decision independent of others decision.

The effect of organizational strength of the tax authority on tax compliance behavior have also examined in the study. It revealed a positive and significant relation between the two implying that effectiveness and strength of the tax authority in awareness creation, service delivery, tax collection and enforcing tax laws will in turn enhance compliance level of taxpayers.

The study has also examined the relationship between tax compliance and perceptions of government spending and has revealed a positive significant relationship which implies that taxpayer's perception of government spending as good will boost their decision to comply with the tax laws of the country.

The study having evaluated the effect of cost of complying with the tax law on tax compliance and concluded that there is a negative and statistically significant relationship between them implying that higher cost of compliance (in terms of both financial and time compliance cost) will lead to lower levels of compliance.

\section{Recommendations}

Based on the findings, in order to make the taxpayers more compliant to the tax system, the following measures should be taken by the tax authority:

- From the study findings it is deduced that fairness or equity of the tax system has a significant effect on tax compliance. The findings suggest that tax systems that are fair (vertical as well as horizontal) are most likely to be complied. Therefore, the tax system should not be in a way that does not encourage taxpayers to evade (the tax system should fair in all aspects that encourages taxpayers to comply).

- The study finds strong support for the argument that penalty highly affects tax compliance, thus there should be moderate and appropriate levels of penalties to be employed. These way owners of businesses will be encouraged to comply since they will act in accordance with the tax laws in order to avoid penalties.

- From the study finding it can be inferred that a perception of government spending has a substantial effect on tax compliance. The finding suggests that perception of government spending as good and important will increase the compliance level of taxpayers. Therefore, the spending of tax revenue by the government should be on social and important projects and information should be forwarded to taxpayers to create a positive image on the spending pattern of the government.
- From the study finding it is deduced that tax compliance cost has a profound effect on tax compliance. The finding suggests that tax systems with low tax compliance costs are most likely to be complied. Therefore, the tax compliance costs should be in a way that does not encourage taxpayers to evade tax that means compliance cost should be kept to the minimum.

- From the study finding it can be understood that tax rate has a negative and significant impact on tax compliance and higher tax rates encourage taxpayers to evade and avoid tax. Therefore it should be in a way that encourages tax compliance behavior and the tax authority is required to keep it as much as possible to the minimum.

- Finally, Tax compliance will be developed just with the voluntary cooperation of the society with the tax authority. Simply relying only on carrot and stick approach has no sweeping result. Hence, the government and the tax authority have to capitalize on responsible citizens' approach in their effort of increasing the level voluntary compliance. Tax evasion and non-compliance is unavoidable in each general public or country. Therefore, it is worthwhile to recommend that the above approach has to be supported by legal enforcement and the efforts must complement each other.

\section{References}

1. Parameswaran R (2005) Public finance and taxation, Addis Ababa.

2. Beza M (2014) Determinants of taxpayers voluntary compliance with taxation in East Gojjam city, Ethiopia. Res J Econ Bus Stud 3: 41-50.

3. Andreoni J, Erard B, Feinstein JS (1998) Tax compliance. J Econ Lit 36: 818-860.

4. Roth A, Scholz T, Witte D (1989) Taxpayer compliance: an agenda for research, Philadelphia: University of Pennsylvania Press.

5. Tadesse GE, Goitom AB (2014) Factors influencing taxpayers, compliance with the tax system: an empirical study in Mekelle City, Ethiopia. J Tax Res 12: 433-452.

6. Amina A, Saniya K (2015) Tax compliance and its determinants: the case of Jimma zone, Ethiopia. Int J Res Social Sci 6: 7-21.

7. McKerchar M, Evans C (2009) Sustaining growth in developing economies through improved taxpayer compliance: challenges for policy makers and revenue authorities. eJournal of Tax Res 7: 171-201.

8. IMF (2011) Revenue mobilization in developing countries, prepared by the Fiscal Affairs Department.

9. Samuel A, Vismanadham P (2013) An assessment of business income taxpayers tax knowledge, tax complexity, and tax compliance: a case of Amhara Regional State of Ethiopia. Int J Sci Res 6: 628-634.

10. Abreha M, Kahase G (2014) Income tax assessment procedures and their practical implementations under Amhara National Regional State: Problems and possible solutions, Thesis, Debre Markos University school of Law.

11. Olamide F, Segun A (2018) Factors influencing voluntary tax compliance of small and medium scale enterprises in Kwara state, Nigeria.

12. Tilahun A, Yidersal D (2014) Determinants of tax compliance behavior in Ethiopia: the case of Bahir Dar city taxpayers. J Econ Sustainable Development 5: 268-273.

13. Kirchler E (2007) Preconditions of voluntary tax compliance: knowledge and evaluation of taxation, norms, fairness, and motivation to cooperate.

14. Palil MR (2010) Tax knowledge and tax compliance determinants in selfassessment system in Malaysia, University of Birmingham.

15. Niway A, Wondwossen J (2015) Determinants of voluntary tax compliance behavior in self-assessment system: evidence from SNNPRS, Ethiopia. Int J Sci Res 5: 967-973. 
Citation: $\quad$ Tilahun M (2018) Economic and Social Factors of Voluntary Tax Compliance: Evidence from Bahir Dar City. Int J Account Res 6: 182. doi:10.35248/2472-114X.18.6.182

Page 7 of 7

16. Oladipupo O, Obazee U (2015) Tax knowledge, penalties and tax compliance in small and medium scale enterprises in Nigeria. iBusiness 8: $1-9$.

17. Lederman L (2003) Tax compliance and the reformed IRS, Indiana University Maurer School of Law.

18. Park C, Hyun JK (2003) Examining the determinants of tax compliance by experimental data: a case of Korea. J Policy Modeling 25: 673-684.

19. Ketema $\mathrm{T}$ (2013) The legal and institutional framework for the Regulation of Tax Avoidance and Evasion in Ethiopia, Thesis, AAU.

20. IMF (2010) Revenue administration: developing a taxpayer compliance program.

21. Clotfelter CT (1983) Tax evasion and tax rates: an analysis of individual returns. Rev Econ Stat 65: 363-373.

22. Torgler B (2007) Theory and empirical analysis of tax compliance, Basel University of Basel.

23. Witte D, Woodbury F (1985) The effect of tax laws and tax administration on tax compliance: the case of US individual tax. National Tax J 38: 1-13.

24. Ajzen I, Fishbein M (1980) Understanding attitudes and predicting social behavior. Englewood Cliffs, New Jersey: Prentice Hall.

25. Warneryd K, Walerud B (1982) Taxes and economic behavior: some interview data on tax evasion in Sweden. J Econ Psychol.

26. Hai T, See LM (2011) Intention of tax non-compliance: examine the gaps. Int J Bus Social Sci 2: 79-83.

27. Puspitasari E, Meiranto W (2014) Motivational postures in tax compliance decisions: an experimental studies. Int J Bus Econ Law 5: 100110.

28. Green WH (2000) Econometric analysis. New Jersey.

29. Yamane T (1967) Statistics: an introductory analysis. 2nd Ed. Newy York: Harper and Row.
30. Due F, Friedlaender F (1981) Government finance: economics of the Public Sector. Illinois, USA: Richard D. Irwin, Inc.

31. Inasius $F$ (2015) Tax compliance of small and medium enterprises: evidence from Indonesia. Institute Bus Finance Res 7: 67-73.

32. Fjeldstad O, Ranker L (2003) Taxation and tax reforms in developing countries: illustration from Sub-Saharan Africa. Chr Michelsens Institutt 6: 1-34.

33. Kasipillai J, Sapiei NS, Eze UC (2014) Determinants of tax compliance behavior of corporate taxpayers in Malaysia. eJournal Tax Res 12: 383-409.

34. Devos K (2014) Tax Compliance Theory and the Literature. Factors influencing individual taxpayer compliance behavior, pp: 13-65.

35. Chau G, Leung P (2009) A critical review of Fischer's tax compliance model: a research systhesis. J Accounting Taxation 1: 34-40.

36. Mogeni E (2014) The effects of compliance cost on tax compliance of companies listed at the Nairobi securities exchange, University of Nairobi.

37. Lemessa B (2005) Federal income tax administration in Ethiopia: the case of employment and business income taxes, AAU.

38. Ali M, Cecil W, Knoblett JA (2001) The effects of tax rates and enforcement policies on taxpayer compliance: a study of self-employed taxpayers. Atlantic Econ J 29: 186-202.

39. Christian CW, Gupta S (1993) New evidence on 'secondary evasion. J American Taxation Association 15: 72-93.

40. Feinstein JS (1991) An econometric analysis of income tax evasion and its detection. The RAND J Econ 22: 14-35.

41. Modugu PK, Eragbhe E, Izedonmi F (2012) Government accountability and voluntary tax compliance in Nigeria. Res J Finance Account 3: 69-76. 